\title{
Mortality in the grower/finisher phase on farrow-to-finish swine operations in the United States
}

\author{
Willard C. Losinger*, Eric J. Bush, \\ Marty A. Smith, Barbara A. Corso
}

United States Department of Agriculture, Animal and Plant Health Inspection Service, Veterinary Services, Centers for Epidemiology and Animal Health, 555 South Howes Street, Suite 200, Fort Collins, Colorado 80521, USA

(Received 6 October 1997; accepted 6 January 1998)

\begin{abstract}
For 327 farrow-to-finish swine operations that had $\geq 300$ finisher pigs and that provided mortality information in the National Animal Health Monitoring System 1995 National Swine Study, conducted in 16 states in the USA, mortality ranged from 0 to $27.5 \%$ in the grower/finisher production phase over a 6-month period. Mean mortality was estimated to be $2.1 \%$ (S.E. $=0.2 \%$ ) during the grower/finisher production phase for farrow-to-finish operations with $\geq 300$ finisher pigs in the 16 states included in the study. Overall, $8.9 \%$ (S.E. $=2.1 \%$ ) of farrow-to-finish operations had $\geq 4 \%$ mortality among finisher pigs. Stepwise logistic regression revealed that operations that used a below-floor slurry or deep-pit waste-storage system in the grower/finisher facility were less likely to have $\geq 4 \%$ mortality than operations that did not have a below floor slurry or deep pit waste storage system. In addition, operations where the average weaning age was less than 28 days had higher odds of having $\geq 4 \%$ mortality than operations that weaned their pigs later. Operations where pseudorabies virus had been diagnosed among finisher pigs in the 12 months prior to interview also had increased odds of experiencing $\geq 4 \%$ mortality. (C) Elsevier / Inra)
\end{abstract}

farrow-to-finish / finisher pig / mortality / national survey / logistic regression analysis

Résumé - Taux de mortalité durant la phase d'engraissement dans les élevages de porcs naisseurs-engraisseurs aux États-Unis. Lors de l'enquête en 1995 du NAHMS (National Animal Health Monitoring System) du département d'Agriculture des États-Unis (USDA : United States Department of Agriculture), 327 producteurs de porcs naisseurs-finisseurs ayant eu $\geq 300$ pores à l'engraissement ont eu des taux de mortalité qui variaient de 0 à $27,5 \%$ chez les porcs à

* Correspondence and reprints.

Tel.: 1970490 7815; fax: 19704907899 ; e-mail: willard.c.losinger@usda.go 
l'engraissement pendant les six mois avant l'interview finale. Le pourcentage de mortalité moyen était de $2,1 \%$ (avec une erreur-type de $0,2 \%$ ). Au total, $8,9 \%$ des éleveurs eurent un pourcentage de mortalité à l'engraissement supérieur à $4 \%$. Une analyse de régression logistique a été utilisée pour identifier les facteurs associés à une mortalité très élevée $(\geq 4 \%)$. Les élevages dont le lisier était recceuilli dans une fosse profonde, en dessous du plancher, avaient une mortalité inférieure à celle des producteurs qui se servaient d'une autre méthode pour stocker le lisier. En outre, les élevages où l'âge moyen au sevrage était $<28$ jours avaient une probabilité augmentée d'avoir de graves problèmes de mortalité $(\geq 4 \%)$. De plus, une mortalité elevée $(\geq 4 \%)$ chez les porcs à l'engraissement était plus fréquente dans les élevages où avait été diagnostiqué le virus de la maladie d'Aujeszky pendant l'année de l'enquête. (O Elsevier / Inra)

naisseur-engraisseur / porc à l'engraissement / taux de mortalité / enquête nationale / analyse de régression logistique

\section{INTRODUCTION}

Using data from the United States National Animal Health Monitoring System (NAHMS) 1995 National Swine Study, Losinger et al. [8] previously reported that a weaning age $<28$ days and obtaining finisher pigs from farrowing units that did not belong to the operation were associated with grower/finisherphase mortality $\geq 4 \%$ among all operations with $\geq 300$ finisher pigs. However, farrow-to-finish operations in the United States are known to be managed quite differently from operations that only have a grower/finisher production phase. Therefore, reasons for high mortality could differ between farrow-to-finish and grower/finisher-only swine operations. In Quebec, Clermont and Désilets [3] reported higher average mortality on grower/finisher-only operations than on farrow-to-finish operations. In contrast, Van Til et al. [16] reported lower mortality on grower/finisher-only operations than among weaned pigs on farrow-to-finish operations on Prince Edward Island.

The purpose of this study was to identify factors associated with high mortality ( $\geq 4 \%$ ) during the grower/finisher phase of production on specifically farrow-to-finish operations with $\geq 300$ finisher pigs in the United States. Results of this study may be useful to researchers in pinpointing areas of further investigation, and to pork producers in indicating potential areas where attention may be warranted.

\section{MATERIALS AND METHODS}

The design and implementation of the 1995 National Swine Study have been described [8]. Briefly, between June 1 and June 16, 1995, enumerators from the USDA:National Agricultural Statistics Service (NASS) visited 1477 participating swine producers in 16 states to administer a questionnaire on general swine farm management. Once between July 17, 1995 and September 13, 1995, and again between November 6, 1995 and January 17, 1996, veterinary medical officers (VMOs) and animal health technicians (AHTs) visited 418 operations that had $\geq 300$ finisher pigs (at the time of the NASS-enumerator visit) to administer more detailed questionnaires that concentrated on feed and waste management, quality control, swine health and marketing. During the second visit by a VMO or AHT (between November, 1995 and January, 1996), swine producers were asked the number of pigs that had entered the grower/finisher phase of production and the number of finisher pigs that had died during the 6-month period prior to interview. Participation was voluntary on the part of the producer.

Analyses in the present study were limited to producers that identified their operations as being primarily farrow-to-finish. Percent mortality was computed from the number of pigs that had entered the grower/finisher unit and the number of pigs that had died in the grower/finisher unit during the 6-month period 
prior to the final interview. SUDAAN, a computer program designed specifically for the analysis of data from sample surveys [11], was used to estimate the mean percent of finisher pigs that died per operation, and the percent of farrow-to-finish operations with specific mortality levels in the grower/finisher production phase.

The chi-square test provided by SUDAAN [11] was used to screen 98 questionnaire variables (previously listed [8]) for possible inclusion in a multivariable logistic-regression model, with the log-odds of an operation having $\geq 4 \%$ mortality among finisher pigs serving as the dependent variable. A limit of $P \leq 0.25$ (based on the chi-square test) was established for a variable to be deemed screened. To scrutinize relationships between potential explanatory variables, Spearman rank correlation coefficients were computed using the CORR procedure of SAS [13] for the screened variables.

Using operations that had provided responses to all of the screened questionnaire variables, forward stepwise logistic regression [7], utilizing the PROBIT procedure of SAS [12], was employed to build a logistic-regression model to identify management factors associated with mortality $\geq 4 \%$. Region, herd size (as measured by the number of pigs that had entered the grower/finisher phase of production on the operation), and average days in the grower/finisher unit were forced into the model. A $P$ value $\leq 0.05$ was required for nonforced variables to stay in the model. Then, using the LOGISTIC procedure of SUDAAN [11] to obtain weighted parameter and standard error estimates adjusted for the stratification and clustering inherent in the survey design, the model developed from SAS was applied to respondents that had provided data for all final model variables.

\section{RESULTS}

Of the 418 operations participating in the second stage of data collection for the 1995 National Swine Study (with on-farm data collection by a VMO or AHT), 345 $(82.5 \%)$ classified themselves as farrowto-finish [15]. For the 327 (94.8\%) farrow-to-finish operations that provided mortality information in the grower/fin- isher phase of production during the 6 months prior to the final interview, mortality ranged from 0 to $27.5 \%$. The weighted national estimate (from SUDAAN) was $2.1 \%$ (S.E. $=0.2 \%$ ) mortality per farrow-to-finish operation. Table $I$ summarizes the distribution of farrowto-finish operations by percent mortality.

Thirty $(30.6 \%)$ of the initially-considered questionnaire variables passed the initial screening phase and were offered for multivariable modeling. The logisticregression model (from SAS) comparing operations with $\geq 4 \%$ mortality and operations with $<4 \%$ mortality (table $I I$ ) was developed from 281 operations that provided data for all of the screened variables. Correlations between non-forced explanatory variables were not strong. The corresponding logistic-regression model from SUDAAN (table III) was based upon 317 operations that provided data for all of the variables included in the model.

\section{DISCUSSION}

The sample weights used here were developed to generate parameter estimates applicable to all operations with $\geq 300$ fin-

Table I. Distribution of farrow-to-finish operations by percent mortality (p) in the grower/finisher phase of production during the 6 months prior to interview.

\begin{tabular}{lcc}
\hline$P(\%)$ & $\begin{array}{c}\text { Percent of } \\
\text { operations }\end{array}$ & $\begin{array}{c}\text { Standard } \\
\text { error }\end{array}$ \\
\hline$P \leq 1$ & 30.8 & 3.9 \\
$1<P \leq 2$ & 35.6 & 4.3 \\
$2<P \leq 3$ & 20.5 & 3.6 \\
$3<P<4$ & 4.1 & 1.1 \\
$4 \leq P<5$ & 1.6 & 0.7 \\
$5 \leq P<8$ & 5.2 & 1.8 \\
$P \geq 8$ & 2.2 & 0.9 \\
& 100.0 & \\
\hline
\end{tabular}


Table II. Results from the logistic regression model which was developed to identify factors associated with a farrow-to-finish swine operation experiencing $\geq 4 \%$ mortality in the grower/finisher phase of production during the 6 months preceding interview (based on 281 operations that provided information for all screened variables in the 1995 National Swine Study).

\begin{tabular}{lcccc}
\hline $\begin{array}{l}\text { Variable/ } \\
\text { response }\end{array}$ & $\begin{array}{c}\text { Odds } \\
\text { Ratio }\end{array}$ & $\begin{array}{c}\text { Lower } \\
95 \% \text { limit }\end{array}$ & $\begin{array}{c}\text { Upper } \\
95 \% \text { limit }\end{array}$ & $P$ \\
\hline $\begin{array}{l}\text { Region (forced into model) } \\
\text { North }\end{array}$ & 1.86 & 0.51 & 6.79 & 0.35 \\
Midwest & 1.37 & 0.46 & 4.04 & 0.57 \\
Southeast & 1 & & &
\end{tabular}

Number of pigs that entered grower/finisher phase

during 6 months prior to interview

(forced into model)

$<800$

$\begin{array}{llll}0.62 & 0.21 & 1.83 & 0.38\end{array}$

800 to 2999

$\geq 3000$

0.66

0.26

$1.68 \quad 0.39$

Average days in grower/finisher unit

(forced into model)

$<800$

800 to 2999

0.34

2.04

0.68

$\geq 3000$

0.79

0.31

2.03

0.63

Below-floor slurry or deep-pit waste-storage

system used in grower/finisher facility

Yes

0.32

0.14

0.73

0.01

No

Average weaning age

$<28$ days

1.31

9.67

0.01

$\geq 28$ days

1

Pseudorabies virus diagnosed by veterinarian or laboratory among finisher pigs in last 12 months Yes No

$\begin{array}{cccc}3.45 & 1.02 & 11.67 & 0.05 \\ 1 & & \end{array}$

States included in each region were: North: Michigan, Ohio, Pennsylvania and Wisconsin; Midwest: Iowa, Kansas, Minnesota, Nebraska and South Dakota; Southeast: Kentucky, Missouri, North Carolina and Ten-

isher pigs in the 16 states included in the study [8]. Since the majority $(82.5 \%)$ of operations participating in the second stage of data collection for the NAHMS 1995 National Swine Study were farrow-to-finish operations, these sample weights were useable to expand the study results to represent farrow-to-finish operations with $\geq 300$ finisher pigs in the states included in the study. Because $18(5.2 \%)$ farrow-tofinish operations that participated in the second stage of data collection did not provide information on mortality in the grower/finisher unit, the results of this study may refer more precisely to the estimated $95.4 \pm 1.5 \%$ of farrow-to-finish operations (within the target population) that were able to furnish information on 
Table III. The result of running through SUDAAN the logistic regression model which was developed from SAS to identify factors associated with a farrow-to-finish swine operation experiencing $\geq 4 \%$ mortality in the grower/finisher phase during the 6 months preceding interview (based on 317 operations that provided data for all model variables in the 1995 National Swine Study).

\begin{tabular}{lcccc}
\hline $\begin{array}{l}\text { Variable/ } \\
\text { response }\end{array}$ & $\begin{array}{c}\text { Odds } \\
\text { ratio }\end{array}$ & $\begin{array}{c}\text { Lower } \\
95 \% \text { limit }\end{array}$ & $\begin{array}{c}\text { Upper } \\
95 \% \text { limit }\end{array}$ & $P$ \\
\hline $\begin{array}{l}\text { Region (forced into model) } \\
\text { North }\end{array}$ & 1.35 & 0.19 & 9.82 & 0.77 \\
Midwest & 0.85 & 0.19 & 3.82 & 0.83 \\
Southeast & 1 & & &
\end{tabular}

Number of pigs that entered grower/finisher phase during 6 months prior to interview

(forced into model)

$<800$

800 to 2999

0.26

0.05

1.38

0.12

$\geq 3000$

Average days in grower/finisher unit (forced into model)
$<800$
800 to 2999
$\geq 3000$

0.29

2.67

0.81

0.47

5.64

0.44

Below-floor slurry or deep-pit waste-storage system used in grower/finisher facility

Yes

No

Average weaning age

$<28$ days

$\geq 28$ days

Pseudorabies virus diagnosed by veterinarian or laboratory among finisher pigs in last 12 months Yes

No

swine mortality. It is possible that the 18 farrow-to-finish operations that did not provide mortality information had higher average mortality than the farrow-to-finish operations that provided mortality information. Therefore, overall mortality on farrow-to-finish operations could have been higher than reported here. No values were imputed for missing data items in the 1995 National Swine Study [8].
Different researchers maintain different opinions on whether sample weights and information about the sample design should be incorporated in the development of multivariable models from survey data [6]. In the 1995 National Swine Study, larger operations were sampled at a lower rate than smaller operations, and therefore contributed less to the error of survey estimates than smaller operations in the study. 
In this case, SAS (which assumes simple random sampling) was used to develop the logistic regression model, which was rerun using SUDAAN (which takes into account the sample weights and study design).

Below-floor slurry or deep-pit wastestorage systems are effective in separating excreta from pigs [5]. A number of diseases can be spread through contact with contaminated manure. Separating excreta from the pigs may reduce the dispersion of certain diseases and subsequent mortality.

Some producers wean pigs at an early age and separate them from the sows to prevent certain diseases [4]. Early weaning also permits sows to breed again more expeditiously [9]. Nationally, $63.8 \%$ of pigs were born on operations where the average weaning age was $<28$ days [14]. Average weaning age proved to be an important predictor of mortality in the analysis that was not restricted to farrow-to-finish operations, even with operations that did not have farrowing facilities included in the model [8]. The results of the present study suggest that a period of time $\geq 28$ days with the sow reduces the odds of an operation experiencing $\geq 4 \%$ mortality during the grower/finisher production phase. However, Van Til et al. [16] list reducing average weaning age as an important opportunity for improving productivity. Therefore, an operator would need to balance the costs associated with later weaning against the benefits of potentially reduced mortality in order to determine an appropriate weaning age.

The survey questionnaire asked about specific diseases diagnosed by a veterinarian or laboratory in the previous 12 months. A response of 'no' had two possibilities: either that the disease agent was indeed absent from the operation, or that the disease agent was present but not diagnosed by a veterinarian or laboratory [8]. In addition, thresholds for identifying and reporting diseases probably varied among individual producers. However, pseudorabies is known to have had a substantial economic impact on the swine industry [1]. The disease is quite contagious and particularly fatal to young pigs [2]. Miller et al. [10] reported higher mortality among finisher pigs in farrow-to-finish herds infected with pseudorabies than in non-infected herds. In our study, diagnosis of pseudorabies virus was significantly associated with high mortality among finisher pigs on farrow-to-finish operations.

\section{CONCLUSIONS}

In a national study of United States farrow-to-finish swine producers with $\geq 300$ finisher pigs, $8.9 \pm 2.1 \%$ of operations reported $\geq 4 \%$ mortality among finisher pigs (which is considered by some researchers as indicative of a serious mortality problem). Results of this study suggested that operations that used a belowfloor slurry or deep-pit waste-storage system were less likely to experience a serious mortality problem than operations that used a different waste-storage system. A weaning age of 28 days or later was associated with reduced odds of high mortality in the grower/finisher unit. Increased mortality was noted among finisher pigs where pseudorabies virus had been diagnosed on the operation during the 12 months prior to the final interview.

\section{REFERENCES}

(1) Beck-Nielsen S., Miller G.Y., Bowman G.L., Dodaro S.J., Orloski-Snider A., Economic impact of an epizootic of pseudorabies in a commercial swine herd in Ohio, achieving test negative status and quarantine release by use of vaccination and test and removal, $\mathbf{J}$. Am. Vet. Med. Assoc. 200 (1992) 1817-1823.

12] Cheung A.K., Investigation of pseudorabies virus DNA and RNA in trigeminal ganglia and tonsil tissues of latently infected swine, Am. J. Vet. Res. 56 (1995) 45-50. 
[3] Clermont R. Désilets A., Aspects épizootiologiques des affections respiratoires porcines qui sévirent au Québec, de septembre 1980 à février 1981, Rev. Vét. Can. 23 (1982) 179-182.

[4] Dritz S.S., Chengappa M.M., Nelssen J.L., Tokach M.D., Goodband R.D., Nietfeld J.D., Staats J.J., Growth and microbial flora of nonmedicated, segregated, early weaned pigs from a commercial swine operation, J. Am. Vet. Med. Assoc. 208 (1996) 711-715.

[5] Fritshcen R.D., Muehling A.J., Flooring for Swine, Pork Industry Handbook PIH-53, Cooperative Extension Service, Purdue University, West Lafayette, IN, USA, 1993, 6 p.

[6] Groves R.M., Survey Errors and Survey Costs, John Wiley and Sons, New York, NY, USA, $1989,590 \mathrm{p}$.

[7] Hosmer D.W., Lemeshow S., Applied Logistic Regression, John Wiley \& Sons, New York, NY, USA, 1989, 307 p.

[8] Losinger W.C., Bush E.J., Smith M.A., Corso B.A., An analysis of mortality in the grower/finisher phase of swine production in the United States, Prev. Vet. Med. 33 (1998) $121-145$.

[9] Mabry J.W., Culbertson M.S., Reeves D., Effects of lactation length on weaning-tofirst-service interval, first-service farrowing rate, and subsequent litter size, Swine Health Prod. 4 (1996) 185-188.
[10] Miller G.Y., Forster D.L., Tsai J., Bowman G., Productivity and profitability differences between pseudorabies-infected and pseudorabies-noninfected farrow-to-finish swine herds, J. Am. Vet. Med. Assoc. 206 (1995) 446-451.

[11] Shah B.V., Barnwell B.G., Bieler G.S., SUDAAN User's Manual, Version 6.40, Second Edition, Research Triangle Institute, Research Triangle Park, NC, USA, 1996, $492 \mathrm{p}$.

[12] Statistical Analysis Systems Institute, Inc., SAS/STAT User's Guide, Version 6, Fourth Edition, Volume 2, SAS Institute, Inc., Cary, NC, USA, 1989, $794 \mathrm{p}$.

[13] Statistical Analysis Systems Institute, Inc., SAS Procedures Guide, Version 6 (Ed.), SAS Institute, Inc., Cary, NC, USA, 1990, 705 p.

[14] United States Department of Agriculture, Swine '95 Part I: Reference of 1995 Swine Management Practices, N186.995, USDA: APHIS:VS, CEAH, 555 South Howes Street, Fort Collins, CO, USA, 1995, 22 p.

[15] United States Department of Agriculture, Part II: Reference of 1995 U.S. Grower/Finisher Health and Management Practices, N201.696, USDA:APHIS:VS, CEAH, 555 South Howes Street, Fort Collins, CO, USA, 1996, 24 p.

[16] Van Til L.D., Dohoo I.R., Spangler E., Ogilvie T.H., A survey of biological productivity of Prince Edward Island Swine Herds, Can. J. Vet. Res. 55 (1991) 174-179. 